\begin{tabular}{|l|l|l|}
\hline \multicolumn{2}{|c|}{ PublisherInfo } \\
\hline \hline PublisherName & $:$ & BioMed Central \\
\hline \hline PublisherLocation & $:$ & London \\
\hline \hline PublisherImprintName & $:$ & BioMed Central \\
\hline \hline
\end{tabular}

\title{
A genome for bioremediation
}

\begin{tabular}{||l|l|l||}
\hline \multicolumn{2}{|c|}{ ArticleInfo } \\
\hline \hline ArticleID & $:$ & 4609 \\
\hline \hline ArticleDOI & $:$ & $10.1186 /$ gb-spotlight-20021014-02 \\
\hline \hline ArticleCitationID & $:$ & spotlight-20021014-02 \\
\hline \hline ArticleSequenceNumber & $:$ & 275 \\
\hline \hline ArticleCategory & $:$ & Research news \\
\hline ArticleFirstPage & $:$ & 1 \\
\hline \hline ArticleLastPage & $:$ & 2 \\
\hline \hline & & \\
\hline ArticleHistory & $:$ & RegistrationDate : 2002-10-14 \\
\hline \hline ArticleCopyright & $:$ & OnlineDate $\quad$ 2002-10-14 \\
\hline \hline ArticleGrants & $:$ & \\
\hline \hline ArticleContext & $:$ & 130593311 Central Ltd2002 \\
\hline \hline
\end{tabular}




\section{Jonathan B Weitzman}

Email: jonathanweitzman@hotmail.com

Metal-ion-reducing bacteria, such as the facultatively aerobic Gram-positive Shewanella oneidensis, offer great potential for bioremediation and the elimination of pollutants - for example, uranium and chromium. In an Advanced Online Publication in Nature Biotechnology, an international team lead by Claire Fraser and colleagues at The Institute for Genomic Research report the sequence of the S. oneidensis MR-1 genome (Nat Biotechnol, 7 October 2002, DOI:10.1038/nbt749). The genome comprises a circular chromosome of almost 5 megabases encoding 4,758 predicted proteins, half of which could be assigned a biological function. The $S$. oneidensis iteron-type plasmid is 161 kilabases and contains 173 genes. The analysis by Heidelberg et al. revealed a 51 kilobase lambda-like 'phage genome, and the authors speculate that this may be a useful tool for genetic manipulation experiments. They found 39 c-type cytochrome genes, more than in any other sequenced organism, and also identified metal hydrogenases and genes involved in metabolism, electron transport, adaptation to diverse environments and pathogenicity. Insights from the $S$. oneidensis genome will be useful for future bioremediation applications.

\section{References}

1. Shewanella Oneidensis, [http://picturethis.pnl.gov/picturet.nsf/All/5D3PVB?opendocument]

2. Nature Biotechnology, [http://www.nature.com/nbt]

3. The Institute for Genomic Research , [http://www.tigr.org]

4. S. oneidensis MR-1, [http://www.tigr.org/tigr-scripts/CMR2/GenomePage3.spl?database=gsp] 